\title{
JUMLAH LEUKOSIT DAN DIFFERENSIASI LEUKOSIT AYAM BROILER YANG DIBERI MINUM AIR REBUSAN KUNYIT
}

(The Number of Leukocyte and Differentiation Leukocyte of Broiler Chickens that be Given the Boiled Turmeric Water on Drink)

\author{
Pristiwanti,N. ${ }^{1)}$, Sugiharto, ${ }^{2)}$ Isroli $^{3)}$ \\ ${ }^{1)}$ Mahasiswa Program Studi S1 - Peternakan Fakultas Peternakan Dan Pertanian \\ Universitas Diponegoro \\ Jalan Prof. H Soedarto, SH, Tembalang 50275, Semarang \\ e-mail : pristinurj@gmail.com \\ ${ }^{2,3)}$ Staf Pengajar Fakultas Peternakan dan Pertanian Universitas Diponegoro \\ Fakultas Peternakan dan Pertanian, Universitas Diponegoro \\ Jalan Prof. H Soedarto, SH, Tembalang 50275, Semarang
}

Diterima : 22 Desember 2016 Disetujui : 13 Mei 2017

\begin{abstract}
ABSTRAK
Penelitian ini bertujuan untuk mengetahui pengaruh air kunyit rebus terhadap leukosit dan differensiasi leukosit ayam broiler. Penelitian dilakukan pada bulan Oktober November 2016. Materi yang digunakan adalah 200 ekor ayam kampung (DOC) ayam pedaging dengan berat awal 41,48 $\pm 0,99 \mathrm{~g}$. Pakan yang digunakan adalah pakan komersial dengan kode B-11S untuk stater fase dan BR-1AJ untuk fase finisher dan kunyit. Desain yang digunakan dalam penelitian ini adalah rancangan acak lengkap (RAL) dengan 5 perlakuan dan 5 ulangan yang masing masing terdiri dari 8 ekor DOC. Perlakuan terdiri dari T0 (100\% air), T1 (75\% air $+25 \%$ air rebusan kunyit), T2 (50\% air $+50 \%$ air rebusan kunyit), T3 (25\% air $+75 \%$ air rebusan kunyit) $\mathrm{T} 4$ (100\% air rebusan kunyit). Hasil penelitian menunjukkan bahwa air kunyit rebus memberikan pengaruh yang signifikan terhadap persentase limfosit dan eosinofil $(\mathrm{P}<0,05)$, namun tidak berpengaruh secara signifikan terhadap jumlah total leukosit, persentase heterofil dan monosit $(\mathrm{P}>0,05)$. Kesimpulan dari penelitian ini adalah bahwa air kunyit rebus dalam air minum ayam pedaging mampu memperbaiki profil darah putih, yang ditunjukkan dengan jumlah leukosit dan persentase limfosit dan eosinofil.
\end{abstract}

Kata kunci: Kunyit, leuycocyte, leucocyte diferensial, ayam pedaging

\begin{abstract}
This study aimed to assess the effect of boiled turmeric water on the number of leukocyte and differentiation leukocyte of broilers. The study was conducted in Oktober November 2016. The material used was 200 Day Old Chick (DOC) of broiler with initial weight $41.48 \pm 0.99 \mathrm{~g}$. Feed used was a commercial feed with code B-11S to phase stater and BR-1AJ for the finisher phase and turmeric. The design used in this study was completely randomized design (CRD) with 5 treatments and 5 replicates containing 8 DOC in each. The treatment consisted of TO (100\% water), T1 (75\% water $+25 \%$ boiled turmeric water), T2 (50\% water $+50 \%$ boiled turmeric water), T3 (25\% water $+75 \%$ boiled turmeric water), T4 (100\% boiled turmeric water). The results showed that boiled
\end{abstract}


turmeric water give significantly affect the percentage of lymphocytes and eosinophils $(P<0,05)$, but did not significantly affect the total number of leukocytes, percentage of heterophile and monocytes $(P>0,05)$. The conclusion from this study is that the boiled turmeric water in the drinking water of broilers was able to improve white blood profile, that indicated by the number of leukocyte and percentage of lymphocytes and eosinophils.

Keywords: Turmeric, leuycocyte, differential leucocyte, broiler

\section{PENDAHULUAN}

Pemeliharaan ayam broiler di Indonesia tidak lepas dari penggunaan obatobatan kimiawi, antibiotik serta hormon yang sebenarnya digunakan untuk memacu pertumbuhan ternak dan menjaga kesehatan ternak (Sinurat dkk. 2009). Di negara maju antibiotik sintetis sudah mulai dibatasi bahkan dilarang penggunaannya. Memperhatikan kondisi tersebut, penggunaan bahan-bahan alami (herbal) seperti kunyit mulai banyak digunakan oleh peternak untuk menjaga kesehatan dan daya tahan tubuh ayam broiler.

Kunyit merupakan bahan herbal yang memiliki kandungan utama seperti kurkumin dan minyak atsiri yang mampu menjaga daya tahan tubuh ternak dari bakteri patogen yang masuk serta meningkatkan sekresi empedu dan meningkatkan nafsu makan (Arfah, 2015). Kurkumin merupakan salah satu sumber antioksidan karena mengandung struktur fenolitik hidroksil yang mampu menangkal radikal bebas, sehingga sistem pertahanan tubuh ternak akan lebih baik (Fahrurozi dkk. 2014). Senyawa fenolik yang terdapat pada kurkumin kunyit bekerja dengan cara menembus dan merusak sel dinding bakteri, sehingga diharapkan mampu mencegah terjadinya peradangan (Wientarsih dkk. 2013). Bakteri patogen yang tidak ada dalam tubuh ternak berakibat pada tubuh tidak memproduksi antibodi secara belebihan untuk agen penyerang bakteri tersebut.
Sel darah putih dan diferensiasinya merupakan salah satu indikator yang pada umumnya digunakan untuk menunjukkan status kesehatan ternak termasuk ayam broiler (Sugiharto, 2014). Setiap individu ternak terkadang memiliki perbedaan jumlah leukosit, yang umumnya perbedaan tersebut disebabkan oleh beberapa faktor meliputi aktivitas fisiologis, umur, gizi, stres dan lainnya, jumlah leukosit yang menyimpang dari kondisi normal mempunyai keterkaitan dengan kondisi kesehatan ternak tersebut (Suriansyah dkk. 2016).

Tujuan dari penelitian ini yaitu untuk mengkaji pengaruh pemberian air rebusan kunyit pada air minum terhadap profil sel darah putih ayam broiler. Manfaat yang diperoleh dari penelitian ini yaitu mampu mengetahui pengaruh pemberian air rebusan kunyit terhadap profil sel darah putih.

Hipotesis penelitian ini yaitu pemberian air rebusan kunyitmampu memperbaiki maupun mempertahankan profil sel darah putih.

\section{MATERI DAN METODE}

\section{Materi}

Penelitian ini dilaksanakan pada Oktober - November 2016. Materi yang digunakan dalam penelitian ini yaitu 200ekor ayam Day Old Chick Broilerdengan bobot badan rata rata 41,48 \pm 0,99 gram. 


\section{Metode}

Prosedur dalam penelitian ini meliputi tahap persiapan, tahap pemeliharaan dan tahap pengambilan data. Tahap persiapan yang dilakukan meliputi kegiatan sanitasi dan biosecurity. Pembuatan kandang flock dengan ukuran $60 \mathrm{~cm} \times 90 \mathrm{~cm}$. Pembuatan air rebusan kunyit dilakukan setiap hari pada pagi hari atau malam hari dengan cara kunyit yang telahdibersihkanditimbangdengan perbandingan 10 gram kunyit dalam 600 $\mathrm{ml}$, dan dimasukkan dalam air yang telahmendidih, kemudianditungguselama 10 menit, kemudiandisaringdan didiamkan agar cukup sesuai dengan suhu ruang sehinggasiapuntukdiberikanketernak. Tahap Pemeliharaan meliputi DOC yang baru tiba ditimbang dan kemudian diletakkan pada flock yang telah diberi alas sekam dan air minum gula. Pemberian perlakuan air kunyit dilakukan pada pemeliharaan hari ke 11, pakan dan minum diberikan secara $a d$ libitum. Pengambilan data dilakukan pada hari ke 28 dengan pemuasaan ternak selama 5 jam sebelum pengambilan darah. Ayam yang diambil darahnya berasal dari 1 ekor setiap unit flock yang diambil secara acak. Darah diambil dari vena pectoralis yang letaknya dibawah sayap dengan menggunakan spuit sebanyak $1-1,5 \mathrm{ml}$.

Setelah itu darah ditampung dalam tabung antikoagulan EDTA dan dikocok membentuk angka 8 dan kemudian disimpan dalam cool box yang telah berisi ice gel.

Perhitungan jumlah leukosit dilakukan dengan metode kamar hitung, differensiasi leukosit dilakukan dengan cara pengamatan preparat apus dengan mikroskop.

Rancangan yang digunakan dalam penelitian ini yaitu Rancangan Acak Lengkap (RAL) dengan 5 perlakuan dan 5 ulangan yang masing masing ulangan terdiri dari 8 ekor ayam. Perlakuan mulai diberikan pada pemeliharaan hari ke 11 yang terdiri dari

$$
\text { T0 (100\% air ) }
$$

$\mathrm{T} 1(75 \%$ air $+25 \%$ air rebusan kunyit $)$

$\mathrm{T} 2(50 \%$ air $+50 \%$ air rebusan kunyit)

T3 (25\% air $+75 \%$ air rebusan kunyit)

T4 (100\% air rebusankunyit)

Data diuji dengan analisis ragam dan jika menunjukkan pengaruh nyata akan dilanjutkan dengan uji jarak berganda Duncan.

\section{HASIL DAN PEMBAHASAN}

Rerata jumlah leukosit dan differensiasi leukosit darah ayam broiler yang diberi minum air rebusan kunyit disajikan pada Tabel 1.

Tabel 1. Rataan Jumlah Leukosit dan Differensiasi Leukosit Darah Ayam Broiler Umur 28 Hari.

\begin{tabular}{|c|c|c|c|c|c|}
\hline \multirow{2}{*}{ Variabel } & \multicolumn{5}{|c|}{ Perlakuan } \\
\hline & T0 & $\mathrm{T} 1$ & $\mathrm{~T} 2$ & T3 & $\mathrm{T} 4$ \\
\hline Leukosit $\left(\times 10^{3} / \mathrm{ml}\right)$ & 225,20 & 270,80 & 487,40 & 334,00 & 377,00 \\
\hline Heterofil (\%) & 34,60 & 24,00 & 18,80 & 23,20 & 29,20 \\
\hline Eosinofil (\%) & $11,75^{\mathrm{a}}$ & $8,00^{\mathrm{b}}$ & $8,60^{c}$ & $14,20^{\mathrm{a}}$ & $2,40^{\mathrm{d}}$ \\
\hline Limfosit (\%) & $51,80^{\mathrm{b}}$ & $68,60^{\mathrm{a}}$ & $69,80^{\mathrm{a}}$ & $59,40^{\mathrm{ab}}$ & $67,40^{\mathrm{a}}$ \\
\hline Monosit (\%) & 1,25 & 0,50 & 1,60 & 1,80 & 0,80 \\
\hline
\end{tabular}

Keterangan : superskrip ${ }^{\text {a,b,c,d }}$ yang berbeda pada baris yang sama menunjukkan perbedaan nyata $(\mathrm{p}<0,05)$ 


\section{Jumlah Leukosit Darah Ayam Broiler}

Berdasarkan hasil analisis statistik pemberian air rebusan kunyit pada air minum tidak memberikan pengaruh nyata ( $>0,05)$ terhadap jumlah leukosit darah ayam broiler pada umur 28 hari. Hasil penelitian ini menunjukkan kisaran jumlah leukosit ayam broiler berkisar 225,20 $487,40 \times 10^{3} / \mathrm{ml}$, dimana jumlah rataan tersebut berada pada kondisi sehat. Jumlah leukosit normal pada ayam broiler berada pada kisaran 12 - $30 \times 10^{3} / \mathrm{ml}$ (Arfah, 2015). Rataan jumlah leukosit pada darah ayam broiler tersebut menunjukkan kondisi yang sehat sehingga ayam tidak melakukan upaya untuk melawan bakteri patogen maupun virus yang masuk dalam tubuh. Ternak yang terinfeksi bakteri akan menyebabkan kesehatan ayam tersebut menurun dengan ditandai adanya peningkatan sel darah putih (Saputro dkk. 2013). Selain disebabkan oleh adanya infeksi bakteri peningkatan jumlah leukosit dapat diakibatkan oleh stress lingkungan yang pada akhirnya mempengaruhi proses fisiologis menjadi abnormal dan mempengaruhi keseimbangan hormonal pada tubuh ayam, kondisi stres ini dapat dilihat dari kondisi lingkungan pemeliharaan yang mencapai suhu 27,13 $31,95^{\circ} \mathrm{C}$ dan kelembaban 67,26 - 93,11\% jauh dari kondisi nyaman untuk pemeliharaan ayam broiler, namun ayam pada penelitian ini tidak mengalami hal tersebut. Peningkatan jumlah leukosit dapat disebabkan oleh stres lingkungan yang meningkatkan produski kortikosteroid dan glukokortikoid yang berpengaruh buruk terhadap kesehatan ayam dan menurunkan sistem pertahanan tubuh (Falahudin dkk. 2016)..

Leukosit merupakan salah satu suspensi plasma darah yang berfungsi sebagai sistem pertahanan tubuh dari serangan bakteri, virus dan patogen melalui mekanisme pembentukan antibodi yang saat ini banyak digunakan sebagai salah satu indikator penentu kesehatan ternak. Status kesehatan ternak dapat diketahui melalui jumlah sel darah putihnya yang memiliki agen penyerang untuk melawan bakteri (Yuniwarti 2015).

\section{Persentase Differensiasi Leukosit}

Berdasarkan hasil analisis statistik pemberian air rebusan kunyit pada air minum tidak memberikan pengaruh nyata $(\mathrm{P}>0,05)$ terhadap persentase heterofil ayam broiler umur 28 hari. Kisaran persentase heterofil pada penelitian ini berkisar 18,8$34,6 \%$ hasil ini masih tergolong normal. Persentase heterofil pada umumnya berkisar $20-30 \%$ (Arfah, 2015). Hasil dalam penelitian menunjukkan tidak ada perbedaan karena ayam dalam kondisi sehat dimana jumlah persentase heterofil pada ayam yang diberi perlakuan air rebusan kunyit cenderung menurun, sedangkan heterofil akan dikeluarkan oleh sumsum tulang ketika terjadi peradangan akut. Peningkatan jumlah heterofil secara cepat terjadi saat peradangan akut sebagai hasil respon yang diterima oleh sumsum tulang sedangkan penurunan heterofil dapat disebabkan oleh menurunnya jumlah parasit (Cahyaningsih dkk. 2007).

Berdasarkan hasil analisis statistik persentase eosinofil pada ayam broiler umur 28 hari berbeda nyata $(\mathrm{P}<0,05)$ antar perlakuan. Persentase eosinofil yang diperoleh pada penelitian ini memiliki kisaran 2,4 - 14,2\% hal ini menunjukkan bahwa persentase eosinofil berada diatas kisaran normal. Jumlah sel eosinofil pada ayam yaitu 2 - 5\% dari jumlah total leukositnya (Arfah, 2015). Persentase eosinofil pada darah ayam broiler pada perlakuan pemberian air rebusan kunyit 
$75 \%$ dan tanpa pemberian air rebusan kunyit lebih tinggi dibandingkan persentase eosinofil ayam yang diberi perlakuan air rebusan kunyit 25\%, 50\% dan $100 \%$. Hal ini diduga pemberian kunyit yang tinggi direspon sebagai benda asing, sehingga tubuh merespon dengan meningkatkan eosinofil, namun pada pemberian kunyit dengan dosis yang lebih tinggi persentase eosinofil menjadi normal. Faktor yang dapat mempengaruhi tinggi rendahnya eosinofil yaitu reaksi dalam tubuh ayam yang berlebihan atau hipersensitivitas respon imun terhadap alergi dan parasit serta tingkat peradangan (Suriansyah dkk. 2016).

Berdasarkan hasil analisis statistik diperoleh hasil bahwa perlakuan pemberian air rebusan kunyit memberikan pengaruh nyata $(\mathrm{P}<0,05)$ terhadap persentase limfosit darah ayam broiler pada umur 28 hari. Persentase limfosit ayam broiler yang diperoleh pada penelitian ini berkisar 51,8 $69,8 \%$ dan berada pada kisaran normal. Persentase limfosit pada darah unggas berkisar $42-66 \%$ (Harahap, 2014). Jumlah limfosit yang tinggi pada darah ayam broiler yang diberi perlakuan T1, T2 dan T4 ini dapat disebabkan oleh adanya kurkumin pada kunyit yang mampu merangsang proses proliferasi sehingga terjadi peningkatan jumlah limfosit Peningkatan persentase limfosit darah ayam broiler yang diberi air rebusan kunyit ini meningkat namun masih falam kondisi normal yang berarti kondisi kesehatan ayam berada pada kondisi optimal. Kurkumin pada kunyit dapat mengaktifkan sel limfosit $\mathrm{T}$ dan $\mathrm{B}$ (Agustanti, 2014).

Berdasarkan hasil statistik diketahui bahwa pemberian air rebusan kunyit pada air minum ayam broiler umur 28 hari tidak memberikan pengaruh nyata $(P>0,05)$ terhadap persentase monosit. Persentase monosit yang diperoleh pada penelitian ini berkisar $0,5-1,8 \%$ hasil ini berada lebih rendah dari jumlah monosit normal pada ayam namun ayam pada penelitian ini berada dalam ondisi yang sehat. Jumlah monosit normal berkisar 3-5\% dari jumlah leukosit di dalam darah (Sismanto, 2007). Rendahnya persentase monosit pada penelitian ini dapat tidak adanya bakteri atau infeksi yang masuk sehingga monosit sebagai pertahan kedua tidak perlu digunakan oleh tubuh. Monosit merupakan garis pertahanan kedua terhadap infeksi, sedangkan penurunan monosit dibawah kisaran normal dapat disebabkan oleh ternak yang mengalami stres (Harahap, 2014).

\section{KESIMPULAN}

Berdasarkan hasil penelitian dapat disimpulkan bahwa pemberian air rebusan kunyit pada air minum ayam broiler mampu memperbaiki profil sel darah putih berupa jumlah leukosit dan differensiasi leukosit.

\section{DAFTAR PUSTAKA}

Agustanti, L. 2014. Gambaran Sel Darah Putih Dan Indeks Stres Ayam Broiler Yang Diberi Jamu Bagas Waras (Jahe, Kunyit, Dan Kencur) Melalui Air Minum. Skripsi. Institut Pertanian Bogor. Bogor.

Arfah, N. H. 2015. Pengaruh pemberian tepung kunyit pada ransum terhadap jumlah eritrosit, hemoglobin, pcv, dan leukosit ayam broiler. Skripsi. Universitas Hasannudin Makasar, Makasar.

Cahyaningsih, U., H. Malichatin dan Y. E. Hedianto. 2007. Diferensial leukosit pada ayam setelah diinfeksi eimeria 
tenella dan pemberian serbuk kunyit

(Curcuma domestica) dosis

bertingkat. Prosiding Seminar

Teknologi Peternakan dan

Veteriner. 593 - 599.

Fahrurozi, N., S. Tantalo dan P. E. Santoso. 2014. Pengaruh pemberian kunyit dan temulawak melalui air minum terhadap gambaran darah pada broiler. J. Ilmiah Peternakan Terpadu (2) $1: 39-46$.

Falahudin, I., E. R. Pane dan Sugiati. 2016. Efektifitas larutan temulawak (Curcuma xanthorrhiza Roxb.) terhadap peningkatan jumlah leukosit ayam broiler (Gallus gallus Domestica sp.). Jurnal Biota (2) 1 : $68-74$.

Harahap, R. A. 2014. Profil Darah Ayam Broiler Periode Finisher Yang Diberi Pakan Plus Formula Herbal. Institut Pertanian Bogor. Bogor.

Saputro, B., P. E. Santoso dan T. Kurtini. 2013. Pengaruh cara pemberian vaksin nd live pada broiler terhadap titer antibodi, jumlah sel darah merah dan sel darah putih. J. Ilmiah Peternakan Terpadu (2) $3: 43$ - 48.

Sinurat, A. P., T. Purwadaria, I.A.K. Bintang, P.P. Ketaren, N. Bermawie, M. Raharjo Dan M. Rizal. 2009. Pemanfatan Kunyit dan Temulawak sebagai Imbuhan Pakan untuk Ayam Broiler. JITV (14) 2: 90-96.

Sismanto, L. H. 2007. Diferensial leukosit ayam pedaging setelah pemberian ekstrak sambiloto (Andrographispaniculata Nees) dengan pelarut metanol dosis bertingkat sebelum diinfeksi
Eimeria tenella. Institut Pertanian Bogor, Bogor.

Sugiharto, S. 2014. Role of nutraceuticals in gut health and growth performance of poultry. J. Saudi Soc. Agric. Sci. Hal: 1-13.

Suriansyah., I. B. K. Ardana., M. S. Anthara dan L. D. Anggreni. 2016. Leukosit ayam pedaging setelah diberikan paracetamol. J. Indonesia Medicus Veterinus (5) 2 : 165-174.

Wientarsih, L., S. D. Widhyari dan T. Aryanti. 2013. Kombinasi imbuhan herbal kunyit dan zink dalam pakan sebagai alternatif pengobatan kolibasilosis pada ayam pedaging. $J$. Veteriner (14) 3: 327-334.

Yuniwarti, E. Y. W. 2015. Profil darah ayam broiler sete;ah vaksinasi ai dan pemberian berbagai kadar vco. Buletin Anatomi dan Fisiologi (23) $1: 36-48$. 